\title{
Global social drama of pandemic and recession
}

\author{
Leonid M. Grigoryev ${ }^{1}$ \\ 1 Higher School of Economics, Moscow, 101000, Russia
}

Received 6 April 2020 • Accepted 16 April 2020 • Published 22 April 2020

Citation: Grigoryev LM (2020) Global social drama of pandemic and recession. Population and Economics 4(2): 18-25. https://doi.org/10.3897/popecon.4.e53325

\begin{abstract}
Global drama of pandemic has caused the deep reduction of consumption of wealthy strata, unemployment and isolation. Huge number of people around the Globe is facing the step back to basic needs by Maslow pyramid: physiological needs and security. Adaptation of people to the new situation goes difficult, while somewhat easier for employed in intellectual activities, primarily for university professors. The exit from recession is still far ahead, and it will depend on the certification of territories, and issue of trust for citizens to start going from their regions. Morals, literature, memories of survival will be close to models of those after the big wars.
\end{abstract}

\section{Keywords}

COVID-19, coronavirus, pandemic, world recession, economic crisis

JEL codes: D31, D63, E21, L83

Where did the Virus come to Russia from? On April 4, 2020 Deputy Prime Minister of Russia Tatyana Golikova publicly said that the countries from where COVID-19 was carried to Russia were Italy, Spain, France, Germany and the UAE. Wealthier people globally had continued to travel by planes as they had "business class" tickets, hotel reservations, and enjoyed despite-everything lifestyle till the very stoppage of the international travel. Our citizens who decided to "quickly" travel to in Western Europe and the Persian Gulf benefiting from cheap tourist packages, played their dramatic role in spreading virus further. Therefore, in the core of the pandemic "imports" to Russia is the Moscow hub. But it is still the secondary wave - Russia managed to avoid the first wave from China, because in January the borders with China were already closed. Taking into account numerous flows between Russia and China (in 2019, 2.8 million Russians visited China, and 1.9 million Chinese visited Russia) Russia could be the main victim of the pandemic. Current reports on the global pandemic are quite frightening: as of April 14, there are almost 2 million sick over the world, more than 100 thousand dead, hundreds of millions self-isolating for months already. 


\section{The first pandemic with reliable statistics}

The current pandemic at the moment is not yet the worst page in the history of mankind compared to "Spanish Flu" and the Great Plague of the 14th century, which had changed the course of social development in Europe. The terrible results of the "Spanish Flu" of the spring of 1918 were mixed with the human losses of the last year of the First World War and were partly overshadowed by the triumph of the end of the war and soldiers returning home. However, as we know, the First World War and the October Revolution broke the relatively stable world that lasted almost a hundred years since the 1816 Vienna Congress and the "Wandering Despot" - Alexander the First. The 1918 pandemic contributed to these outstanding catastrophes. The end of the war, the collapse of several empires, and revolution in Russian almost coincided with the pandemic in time. After that, the world entered a new unstable balance between the two world wars. And the Great Depression of 1929-1932 had shocked the economies of developed world, especially USA and Germany. So, it is why we are looking back to this case for the evaluation of the worst possible scenarios. Paradoxically, we have a better understanding of the consequences of the 1340s plague: the loss of half of Europe's population and the increase in man-made assets per capita; the undermining of serfdom after growth of independence of cities in 11-13 centuries; reduction of craving for crusades; and return of good ecology and large animals Naturally, some know-it-alls draw the future after the current pandemic-related recession with amazing confidence - they need to capture the public attention. Still it is the first (hopefully the last) such a pandemic at the time of highly sophisticated weapon and Big Data. This calls for more responsibility of science!

\section{The global lockdown}

First, let's make sure that we commonly understand the situation as of April 10, 2020. Social, cultural, and personal life, as we knew it recently within more or less developed countries (1.5 billion people out of 7.5) was hedonic, mobile, very unequal between social groups and geographical regions. It is all frozen from March and, apparently, until the summer of 2020. The epicenters of this social blockade are Western Europe and the USA. An increase in the number of sick is everywhere, although as of April 2020 main losses were in New York, Lombardy, France and Spain. Everyone is closely watching Sweden, where the incidence is increasing, but it continues to "experiment on itself" without imposing lockdown, hoping for a Scandinavian lifestyle and the acquisition of "herd immunity".

China is beginning to restore production with significant restrictions. India closed down in fear of repetition of the "Spanish Flu" (around 25 million dead in that pandemic) (Profile 2020). Other developing countries, with their inequality and population overcrowding in big cities, face serious challenges and risks, but this is the topic of a separate work. So far it is necessary to simply state that developed countries have lost their "Role and Face" in the world theatre. Their health systems did not survive the first strike, although in principle they should win the war against the virus by gathering forces in the future. Meanwhile China has stopped the spread of infection inside the country, resumed exports of masks and other supplies to OECD countries. At a critical moment of the pandemic politicians are debating the growth of China's soft power, as it began to aid a number of countries with doctors and materials. Russia has turned capable of some assistance to other countries at the time of global paralysis of cooperation. 


\section{COVID as a trigger of recession}

The second important feature of this doubled (pandemic-recession) crisis is that the trigger that time was not shock from debt, bank bankruptcy, as it was in 2008. This time it starts by bans on certain types of personal consumption and activities for medical reasons by the order of the States. In the developed countries several large sectors were stopped: retail trade (except food and pharmacies), air transport, a significant part of road and sea transport. The entire world system of mass recreation came to a halt: from picnics and zoos to large stadiums and whole tourist zones. Such lockdown will impact small countries, islands in the tropics, and will be followed by balance of payment and budget crises. An exception is expected to be pharmacology, health care, food stores, home delivery, distant education etc. The first characteristic feature of the pandemic is that virus was carried by not poor but by wealthier strata: "upper middle class" in business trips and in business class tourism; "middle middle class" in mass tourism.

The IMF is now elaborating aid programs ASAP for half the world, but supporting budgets is unlikely to prevent social crises. The spread of the crisis by a chain of industries in the world goes from final personal consumption and has already caused a reduction in production, consumption, exports. Capital formation will go down soon. The first to be hit were the enterprises by the chain in trade, tourism, transport and all large small and medium businesses in developed countries. As a result, there is a sharp fall in GDP, financial and debt problems of business translate the situation into a deep global recession.

The World Economic Outlook released by the IMF in April (IMF 2020) gives the evaluation of the current situation and forecast for 2020 and 2021 on a key assumption that pandemic will end in the first half of 2020. In our opinion, the forecast is too mild and calm against the Great Lockdown which is happening everywhere now. Decline of the global GDP is foreseen by "only" $-3 \%$ (reminder: $-0,5 \%$ in 2009 ) and decline of the world trade by $-11 \%(+8,4 \%$ in 2021). This will happen if oil price (thanks to the OPEC+ policies) will be USD35,61 in 2020 and go up to USD37,87 in 2021. GDP growth in China is projected to stay positive at $+1,2 \%$ (and $+8,5 \%$ in 2021). Aggregated GDP advanced economies will reduce by $-6,1 \%$ but will increase by $4,5 \%$ in 2021 . According to this forecast in 2020 GDP of Russia will decline by $-5,5 \%$, USA by $-5,9 \%$ and EU by $-7,1 \%$. IMF is pretty optimistic for 2021 : recovery for the World by $+5,8 \%$, Russia by $+3,5 \%$, USA by $+4,7 \%$ and EU by $+4,8 \%$ (IMF 2020 ). IMF obviously expects the stability of OPEC+ arrangements and absence of other aggravating problems and conflicts. Strictly speaking this forecast gives not the worst scenario, while still very harsh for the population of the most of countries. It can be said that the IMF forecasts significant shift of the global balance in favour developing countries, namely China.

There is an element of luck though - the crisis is already rather harsh, but it is something like an "induced coma". It might not have occurred, and it did not begin in the acute final period of overheating at the end of the cyclical upturn, the period of imbalances, the liquidity crunch, the beginning of bankruptcies, "as it normally was". This gives some chance for the economy to recover if the pandemic is exhausted itself before the Autumn and all of the above-mentioned industries are reopened. However, it is difficult to imagine a rapid certification of "cleanliness" from the virus of countries, cities, resorts and even restaurants. It will be similar to opening regions to foreign tourists after terrorist attacks. After it has already settled down, but it is difficult to guarantee security for the returning people and businesses. In the case of the second virus wave, which may begin somewhere by neglect or due to a mutation of the virus, the situation would become quite uncertain. 


\section{The depressing sociology of the moment}

So far, we are to limit ourselves to the most realistic characteristics of the ongoing social processes, when the inhabitants of all countries have fear of the terrible disease until new poverty has not accumulated and apathy and indifference from prolonged isolation fatigue have not come. In the foreseeable future (depends on the length of the pandemic-recession), a sense of hopelessness and dependence on the pandemic and all the associated limitations can cause worldwide demand for changes in the status quo and new ideas, which may be very strange in such a situation. So, our agenda for April 2020 is short, but this list of Big Questions is likely to be re-visited:

- How is the socio-economic environment changing?

- What sectors of the world economy are affected?

- Which social strata were badly affected and which was not so bad?

- What's going on with inequality?

- What are the withdrawal and adaptation like according to Maslow pyramid?

- What are the short-term and long-term changes in life of families?

So, lots of people around the closed-from-virus world are at least isolated, confined to families, deprived of usual occupations and usually part of their income. However, the cessation of personal consumption of the wealthy strata of society is the third and extremely unusual feature of this recession: it is an exceptional trend of equalizing consumption. The wealthy (richest fifth $20 \%$ group) are probably the least affected by falling incomes. Even affected businessmen should not experience instant loss of personal income and savings. The stop in habitual consumption means a forced increase in the rate of savings and, to a certain extent, potentially the delayed demand for travel, restaurants, etc., including purchases of durable goods. Normally the crisis phase is characterized by the effect of a "protective consumption pattern" when consumption spending is being reduced more than income decreases (Grigoryev and Salmina 2009). Income and wealth inequality appears to be increasing in the future, while inequality in current consumption decreases for a short period of time - the effect of "war". Now, there is an experiment for the economy of peacetime - compression of consumption during an unfinished boom with uncertainty of its timing. Walter Schneidel was right in his "Great Leveller" (2017) that wars, catastrophes and pandemics (i.e. violence in the broad sense) reduce inequality.

\section{Here the Maslow pyramid comes}

Now different social strata, groups by education or by hobbies (from football to conservatory) are deprived of the opportunity to fill their time. Instead, everyone is offered an unlimited television and information networks. If we look at the situation from the perspective of the Maslow pyramid, we may see great losses on the third and fourth levels - social belonging and esteem. Although, of course, respect and esteem are directed at medical workers. The top three levels related to self-actualization, creativity and spiritual needs, are now facing inwards, directed towards family or few close associates, and also to forms of implementation that are available throughout networks. Suddenly, society has been driven back - without loss of wealth and education - to the basic levels of physiological and safety needs. It will not go later without a trace for the people as an experiment in a group for psychological research. It will have long-lasting impact on a lot of people as a mass experiment and for an indefinite time. 
One more (the fourth) unusual feature of this recession is socio-economic. This is the forced stopping of the services sector because the need to eliminate the overcrowding of people can stop infection spreading. This is the first time when services were seriously damaged by the crisis, moreover, they became a trigger. The specificity of services where production and consumption occur simultaneously, creates a number of forks. Individual services (e.g. hairdressing) are one matter, while theatres is quite another. The stopped service sector has different impacts on those who lost the service and usual lifestyle, and those lost income. For example, usually, if one client does not tip in a restaurant, it is unpleasant, but does not seriously affect income of the waiter and the institution. But if now customers do not tip waiters, it means savings for the ones and loss of basic income for the others. Everyone needs to look for forms of maintenance of efficiency, new forms of earnings. Perhaps nations with a tradition of individual closeness take the forced isolation easier than for example Mediterranean nations based on communication, restaurants and tourism.

\section{To rally in isolation}

In a period of acute crisis people usually try to rally, unite in groups, keep up with their loved ones and families. In the present situation, the fight against the virus requires isolation from each other, which is technically and psychologically difficult. We have been lucky with timely arriving of digitalization, remote teaching opportunities and Internet access to networks. It is, of course, difficult to replace active working life with passive observation. Staying at dachas in principle simplifies isolation. In Russia, the ratio of the number of dachas to families in cities is much higher than in developed countries, where the second home in the countryside is a sign of belonging to the upper-middle or upper-class (perhaps within the 10th most wealthy decile). Inherited from Nikita Khrushchev's era "six hundred square meters of land" provides the opportunity to isolate family members, however, virologists are concerned about infection through shops and the difficulty of control and provide medical aid in distanced settlements. In April, in European Russia people still prefer to stay in their city apartments. However, in early May lots of people will rush to plant seeds, look after flowers and fruit treesю It can become a new social threat for containing infection.

\section{Who is less hit by the pandemic}

Psychologically, lockdown is easiest for professors, who are rather overloaded by work than unloaded with lectures and lessons online: "zoom at home". But here, there are problems as well. The general basic knowledge can be conveyed at remote lectures. Students save time on transportation, but it is more difficult to skip lectures - the professor sees online the attendance. Of course, one can slumber at home at a lecture, but the computer is occupied by online lecturing and it can be hardly used for other activities. The situation with term papers is more complicated as they require more individual work. And most importantly, it is still unclear whether it is possible to realize the «Socrates dialogues» online. Let's imagine Raphael Santi's fresco “The School of Athens” in Vatican: philosophers and pupils in togas sitting on the steps... some of them in Zoom, others in Skype. Aristotle and Leonardo are communicating via "WhatsApp", Michelangelo is sad as his notebook lost Internet contact, Alcibiades and Socrates are distanced for 2 meters. A very serious post-graduate student 
in white toga is thinking whom to address for her thesis review. Diogenes of course made himself well isolated.

In our case, the opportunity for a dialogue with colleagues remains. The speed of transmission of information is standardized by technology, although it is much more difficult to differentiate the work with students of different levels of training and type of perception. However, effectiveness of working in depth with smart younger colleagues is in question. We are to think of something that would preserve the privacy and depth of dialogue in our peculiar professional language that is usually elaborated within certain science schools, both in studies, projects and at tea parties. It will not be possible to visit cafes with colleagues soon, it is better not to look forward to it. Although the people with the activities associated with the upper levels of the Maslow pyramid will more easily tolerate isolation and capable of restructuring of horizontal links, will faster and easier adapt to restoring the elements of "old life".

\section{Social isolation does not mean isolation of one's spirit and brain}

An important aspect of isolation is the restructuring of spiritual life. It is a well-known fact that in times of war many turn to God, although sometimes they conceal it. Others hope for a miracle of salvation, recovery. The Church as an institution will also have to rebuild, but it is also an opportunity to carry out important moral messages about love for one's neighbor, consolation, help, compassion. During the plague in Europe in the Middle Ages (and in Italy today) many priests died simply because dead people were brought to the church for burial service. Isolation is important here too and the sermon will take place on social networks worldwide.

Well-to-do businessmen are rapidly adapting as they have been largely digitalized before. State officials are easier to govern at some distance from alarmed citizens, and politicians need not only work effectively but also prove that it is so. When the pandemic comes to an end, and the recession will still be tormenting firms and people - that's when the psychological reassessment of the past will begin. Only medical workers are constantly at the forefront and employees of services providing infrastructure and vital services and food chains are at work, not in isolation and under threat to health.

\section{The stairs went backward}

Returning to sociology, we can make a sketch of the situation and reactions not by industry, but by social strata. Migrant workers who have lost job or a part of their income in Russia and worldwide will be in the worst situation: they can neither return home nor send financial support. "Local poor" around the world (especially in developed countries) will somehow be supported by the state and charity. Perhaps the common danger will increase solidarity and assistance to those most in need. It will be much more difficult to help the poor in other countries, and partial paralysis of transport and especially sanctions already pose problems for the delivery of protective equipment, medicine and food to refugee camps and in general to those in need.

The structure of employment by sector of the economy will change significantly after the pandemic, but this is a separate topic. The unemployment in the US is already a huge problem - the labour market is very flexible there. In Europe, small businesses are often operating in closed industries, with the share of employment in affected industries is $20-25 \%$. In 
Russia tourism industry is smaller, and after the pandemic it will be easier for the industry to revive on internal tourism.

The nowadays reduction of individual expenditures is forcedly equalizing people, although the wealthy people have higher quality and patterns of consumption. Full recovery to the previous consumption level and structure will not occur immediately. So, the middle classes will survive, but with some decline in welfare. Inequality in income and in assets (especially in real terms) will quickly return, particularly due to the mass loss of income by the unemployed.

\section{This too shall pass...}

Someone will profit, as always during crises, from cheaper assets, someone will write a book, someone will finally get married (or divorced). Deferred transportation services of all kind will gradually get restored. Durable goods remain partially not damaged: TV, computers, gadgets, washing machines, exercise devices are needed in isolation more than usual. It may be hoped that the money saved at home will later turn into fashion and dresses, ties and hats after the bored jeans, T-shirts and sweaters.

The exit from the crisis will be based on the conclusions of virologists, decisions of officials and trust of citizens. It will be necessary to have some courage to go to a restaurant and the theatre after confinement. Imagine the joy of children in parks, adults "again in the Tretyakov Gallery" and companies making up for missed birthdays - this will be an easy recovery. But as for travelling (by plane!) to another country to a resort - this will be just like after a terrorist attack long ago, for the masses in any case. WHO, national epidemiological authorities will have to provide some sort of certification of cities (source of tourists), resorts with their migrant workers staff, in order to restart the world's tourist industry and transport. In particular, this applies to cruise vessels which were affected - not many of them were subject to this, but it was on television for a very long time. Probably, here bilateral friendly agreements will be needed, in particular with partners (EAEU, China, BRICS countries) on restoration of reliable city-resort routes (I will not name them here to avoid advertising). Active advertising of countries, islands and resort areas will begin with the slogan: "We had no COVID-19 cases at all!"

Not only remote islands and tropical resorts or "coasts" within large countries are under the threat of downtime in the 2020 tourist season. At the end of March, only 60 thousand flights per day were made in the world instead of the usual 180 thousand. Probably, the Great Mediterranean Tourist Empire - approximately within the boundaries of Roman Empire - will lose most of the season (at best). Countries with high levels of infection (Italy, France, Spain) will need more time to clean up the consequences, certify and restore the confidence of foreign tourists. It is clear that domestic resorts will be opened first in all countries - there will be tough advertising competition, protectionism, industrial policy, and import substitution, all "in one bottle".

\section{This pandemic will be never forgotten}

Time will pass and the memories of those who survived the Pandemic-recession-2020 will be very different. Human losses are the most terrible and memorable in any war, so will it be here. Most people will breathe a sigh of relief and generally try to make up for what they 
missed - health, career, sports. Probably, in our memories of this time - with all the differences between countries, social strata and cultural codes. There will be elements of the "Stockholm Syndrome", i.e. we will gradually forget the boredom and agony of isolation and remember how we survived. However, there will be no great variety of stories as the entire world faced the same problem, but there will be more nuances. Finally, we are waiting for streams of love novels and detective series such as "love and blood in the era of the pandemic": masks, wrong diagnoses, viral beauties in protective suit, treacherous friends and lost properties.

In our country, demographic situation is unlikely to be improved during the pandemic and recession - the uncertainty of the future is too high, and at two meters of distance it is difficult to fall in love even in the movie. Too much medicine, little communication, little personal acquaintances - WhatsApp will never substitute for the fragrance of perfume and visual perception. It is impossible to gather and listen to The Decameron - the police will not allow getting there and masks will not helpful. TV Beauty Show or song festivals on TV and in networks are possible without spectators in the hall. But what are the great prospects for Venetian masks and festivals! We will have to establish the International Victory Day over the Coronavirus - to honor medical workers and remember the passed away dear ones! Whether people will become better after the trials we will discuss another time when there is more information about the real severity and duration of the pandemic and recession. But let's hope for a "post-pandemic baby boom".

\section{Reference list}

Grigoryev L, Salmina A (2009) Forced self-defense. Changing the personal consumption pattern under the crisis. Vremya Novostei [News Time] \#164 09.09.2009 http://www.vremya.ru/print/236885. html (in Russian)

IMF (2020) World Economic Outlook. The Great Lockdown, April 2020: Chapter 1. https://www.imf. org/en/Publications/WEO/Issues/2020/04/14/weo-april-2020

Profile (2020) Why India manages to successfully resist COVID-19. 19.03.2020. https://profile.ru/ abroad/pochemu-indii-udaetsya-uspeshno-soprotivlyatsya-covid-19-259902/?fbclid=IwAR0k9N1U6H67LhxjI_JVQqVof5_hogfq8x-Q3SPLw9EccGtwkml-7dH1Goo. (in Russian)

Scheidel W (2017) The Great Leveller: Violence and the History of Inequality from the Stone Age to the Twenty-First Century. Princeton University Press. 504 pp.

\section{Information about the author}

- Leonid M. Grigoryev, Tenured Professor, Academic Supervisor of the School of World Economy at the Faculty of World Economy and International Affairs, Higher School of Economics.lgrigoriev@hse.ru 